suitability of varieties for cross pollination. Some varieties of pear which did not overlap their blossoming times in 'long flowering period years' (1939 and 1941) did so in years with short flowering periods (1940 and 1942). The approximate flowering times of 320 varieties of apple and 138 varieties of pear have been listed.

Alpha-naphthalene acetamide has been used by Dr. Lewis to prevent 'June-drop' in cherries, plums and pears. This substance is applied in aqueous solution or in lanolin to the styles and flower stalks. It delays abscission of the style for two days, thereby giving greater possibility of pollination, and therefore increased fertility.

Dr. K. Mather and his staff in the Department of Genetics have studied the question of polygenes, which are now found to form balanced combinations within the chromosomes under the action of natural selection. Several new lines of approach are thereby opened to problems raised by the behaviour of wild and cultivated plants.

An interesting result from the Department of Cytology is the production of tetraploids by the use of colchicine in species of Nicotiana and related genera.

The Garden Department, under Mr. W. J. C. Lawrence, maintains an extensive advisory service, and has carried out experimental work on the wartime use of fertilizers.

The report of the director, Dr. C. D. Darlington, announces the help of the Agricultural Research Council in the prosecution of new work on the conditions of breeding and maintenance of cultivated varieties of plants. Many other results of the Institution's work are recorded briefly in the report.

\section{PROBLEMS OF AMERICAN UNITY}

$\mathrm{T}$ WO remarkable pamphlets, bearing the titles "National Unity through Intercultural Education" and "What Democracy Means in the Elementary School", have been published by the U.S. Office of Education at Washington. They belong to a projected series* of about twenty, some of the other titles being "Our Country's Call to Service", "What the Schools Can Do" and "Hemisphere Solidarity". The whole series bears the title "Education and National Defense". Everyone agrees, says the U.S. Commissioner of Education, that "the schools must become increasingly vital centres for the education of youth and adults facing a war-torn world. But how ?" That is the question which this series is meant to answer.

The answer cannot be so easy for the United States as it is for Great Britain. We all know well enough for practical purposes what is meant by being an Englishman, but here we have a representative American seriously raising the question-"What is an American? Who is he? Is he of Anglo-Saxon background, which group makes up half the American population ? Or does he represent the 15-20 millions of German background, the 5 millions of Italian, the 4 millions of Scandinavian, the 2 millions of French, or the 8-10 millions of various Slavic backgrounds ?" We are all familiar with the metaphor of the meltingpot, but it is hard for the untravelled Englishman

- Education and National Defense Series (Federal Security Agency, U.S. Office of Education, each 15 cents) to realize the immensity of this melting process, and to grasp at once the inner significance of this series of broadcast pamphlets. It is the latest manifestation of the fact that an essential part of the melting process is the system of education. America's lavish support of her schools and universities is due not only to her democratic desire to banish ignorance, but also to her desire to take the quickest and surest road towards national unity.

The pamphlets, which are beautifully produced and abundantly illustrated, contain specific suggestions for the adaptation of the established curriculum to new needs, and they present materials suitable for various educational levels from the primary school upwards. Every care is being taken to secure help and sympathy from teachers and officials in all parts of the United States, to ensure the success of the enterprise.

One reflexion should ever be in the mind of the Englishman as he contemplates the great American war effort. American history, of which he is not quite so ignorant as he used to be, is the history of a gradual union of what were originally a number of independent States, and she can no more get away from the strong tradition of "States rights" than a man can walk away from his own shadow. In many respects the strength of the States, and the corresponding weakness of the central government, has been, and remains, a great advantage. But it is beginning to be realized that America must face her enemies, not as forty-eight States, but as a united nation. This series of pamphlets, issued by the U.S. Office of Education at Washington, and appealing to the whole of America, is perhaps something more than a straw indicating the direction of the wind.

T. RAYMONT.

\section{POST-WAR PLANNING OF PSYCHOLOGY IN THE UNITED STATES}

\section{$T$} HE National Research Council of the United States, the Government-endowed body which promotes research in America, has a division devoted to research in anthropology and psychology. Soon after the outbreak of the present War this division established an Emergency Committee in Psychology on which representatives of the American Psychological Association and other psychological societies were asked to serve. In May 1942, the American Emergency Committee formally recognized longrange planning for the advancement of the profession of psychology as one of its fundamental problems. A group of six psychologists was appointed to prepare a report for the Committee on the immediate and post-war measures that appeared desirable for the promotion of psychology as a profession.

This Committee has considered how the psychnlogical profession might be unified and urges the formation of a single national centre to be known as the American Institute of Psychology*. This central national institute would serve as a 'professional union' of psychologists corresponding to the British Medical Association, which unifies the medical profession. Secondly, this institute should aim at inte-

* Post-War Planning for Psychology, Occupational Psychology, 17, No. 2 (April 1943). 